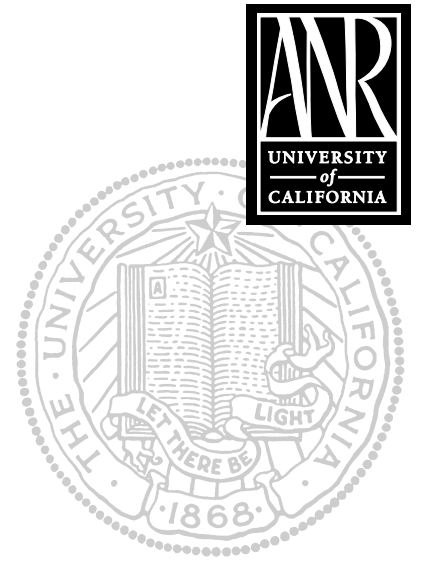

UNIVERSITY OF

CALIFORNIA

Division of Agriculture and Natural Resources http://anrcatalog.ucdavis.edu

\section{PUBLICATION 8101}

\section{Key Points of Control and Management for Microbial Food Safety: Edible Landscape Plants and Home Garden Produce}

TREVOR V. SUSLOW is UC Cooperative Extension Specialist, Department of Vegetable Crops, UC Davis; and LINDA HARRIS is UCCE Extension Food Safety Specialist, Department of Food Science and Technology, UC Davis.

Most fresh fruit and vegetables consumed in the United States are wholesome and free of disease-causing microorganisms so long as they are subject to common and sensible food handling and preparation practices. Many fruit and vegetables have natural barriers, like skins and rinds, that minimize the chances that any surface contamination could be transferred to the internal edible portions. These protective barriers can guard the internal parts up until the point of harvest. The same barriers can also make washing or light to vigorous brushing of produce more effective, depending on the fruit or vegetable's sensitivity to brushing.

Contamination with microbial pathogens can only come, ultimately, from an external environmental source that is, from a source outside of the fruit and vegetable, and that can occur at any time from planting through food preparation. The best approach to maintaining the wholesome nature and safe consumption of your home garden's harvest, just as with any fruit or vegetable that you eat uncooked, is to be aware of potential risks and to establish commonsense practices that will minimize the chance of contamination.

\section{BACKGROUND}

Whether fruit and vegetables are produced domestically or imported, four key events have focused general attention and concern on the microbial food safety of fresh fruits, vegetables, nuts, and other edible horticultural foods:

1. Recent recurring outbreaks linked to consumption of imported and domestic products.

2. Positive detection and recovery of human pathogens from random survey samplings of both imported and domestic produce.

3. Recent consumer surveys that document the inconsistent practices of consumers in the cleaning and washing of produce surfaces.

4. Recent reports from several researchers documenting the potential for internalization of pathogens into produce- particularly during harvest and handling.

When you consider the overall consumption of fresh produce in the United States, most foodborne illnesses are more likely to arise from contamination during food preparation and storage. However, it is equally clear that some outbreaks have been linked to fresh produce from specific production areas, and that these have impacted large numbers of people. 
The home garden and edible landscape environments are not free from the potential of contamination by human pathogens. Certain aspects of the gardening environment may actually increase the risk from some sources of contamination. While most individuals can recover from foodborne illness without complications or the need for medical attention, others such as the very young, the very old, and those whose immune systems may have been compromised are at greater risk and can suffer complications and even death.

This publication provides a brief outline of the important components of microbial food safety practices of which we should all be aware. The diversity and scale of home garden environments, gardening practices, and food handling practices make the idea of a single approach to food safety planning in the garden unrealistic; instead, this publication will focus on the key guiding principles of preventing contamination, reducing the survival of pathogens, and preventing cross-contamination at each step. You can develop an individual food safety plan for your home garden by applying these principles, which are drawn from research and practical experience.

\section{WHAT ARE THE GUIDING PRINCIPLES OF MICROBIAL SAFETY FOR FRESH PRODUCE?}

- Once produce has been contaminated, the pathogens are very hard to remove or to kill.

- Prevention of microbial contamination at all steps, from production to consumption, is much more effective than efforts to "clean the produce up" after it has been contaminated.

- Food safety awareness is the essential tool for designing and implementing a home garden strategy for preventing foodborne illness.

\section{Guiding Principles for Water}

Wherever water comes into contact with fresh produce, the water's quality may directly determine the potential for pathogen contamination and its persistence.

- Become familiar with the seasonal quality of any surface water sources used for gardening or edible landscape management. Surface water can include water from ponds, lakes, streams, and any other water source that is directly exposed to the environment.

- Identify potential sources of contamination that affect your water, especially those that are within your ability to control in a manner that will protect water quality.

- Ensure that home wells are designed and maintained in a manner that will prevent surface runoff or soil infiltration from contaminating the water supply.

- Irrigation methods such as trickle irrigation that minimize contact between the water and the edible parts of the plant will reduce the potential for contamination.

- Water used for foliar applications should be from a pathogen-free source such as a municipal water system.

- Water used for cleaning fresh produce at harvest should also be from a pathogenfree source.

- Carefully review all uses of graywater for irrigation of edible garden plants. Be sure you are not using any water that could contain the microorganisms that cause foodborne illness. 


\section{Guiding Principles for Manure}

Properly composted animal manures, domestic green manures, or municipal biosolids are not a source of microbial pathogens on fresh produce.

- Become informed about proper home compost management for pathogen reduction, especially if your are using any animal manure.

- Maximize the time between your application of animal manure to garden areas and your harvest of edible crops.

- Spreading animal manures without incorporating them into the soil requires careful attention to ensure that pathogen-reduction practices have been met. Recommended pathogen-reduction practices and time:temperature guidelines to optimize pathogen reduction are available online at http://ucgaps.ucdavis.edu.

- Gardening practices that use manure slurries or manure teas for pest control and foliar nutrients on any landscape or garden plant should be carefully evaluated for how likely it is that they will result in the direct or indirect contamination of edible crops.

- Make sure that any septic system is properly installed and maintained. Faulty septic systems and poorly designed drain fields have caused foodborne illnesses and pathogen infections in the home environment.

\section{Guiding Principles for Minimizing Animal Fecal Contamination}

It is not possible to eliminate all influences of animals from the garden environment, but you can take certain steps to minimize their presence or activities.

- During the growing and harvest seasons, keep domestic animals and pets out of areas with edible plants.

- Carefully consider whether weed-eating geese or pest-eating ducks and chickens are sensible additions to your edible garden or edible landscape plantings. Fecal contamination from these animals has been linked to incidences of foodborne illness.

- Minimize vegetation at the edges of small fruit and vegetable patches. They can serve as gathering, nesting, or hiding places for animals (rats, mice, etc.) that serve as vectors of human pathogens.

- Minimize the presence of vector attractants (such as piles of decaying fruit and vegetables) adjacent to your garden.

- Minimize the opportunity for vectors to contaminate any harvest equipment surfaces (bins, totes, gloves, boxes, buckets, bushel baskets).

\section{Guiding Principles for Personal Hygiene and Gardening}

There is no substitute for being fully aware of the importance of personal hygiene and sanitation in preventing foodborne illness in the home. This awareness should constantly be reinforced, especially among children.

- Establish family awareness of proper handwashing techniques, with special attention to cleaning around the fingernails.

- Be aware of the potential for garden gloves to transfer contamination from one place (such as a compost bin) to pre-harvest or harvested produce.

- Be aware of children's habits in the garden, especially toddlers in diapers, in handling potentially contaminated material or playing with or petting domestic animals (turtles, cats, rabbits, chicks, etc.). 


\section{Guiding Principles for Garden and Harvest Sanitation}

All surfaces and implements that touch fresh produce must be treated as food contact surfaces. Well-planned food handling practices in the garden and home can reduce the likelihood of pathogen contamination. Careless handling has the potential to spread localized contamination or create opportunities for pathogen contamination of other foods within the home.

- Clean all food contact surfaces and harvest containers or bins prior to use.

- Develop a system of cleaning and sanitizing for food-contact surfaces that is compatible with the home environment. Chemicals such as dilute bleach, trisodium phosphate (TSP), dilute peroxide, and dilute white vinegar can be used safely and effectively if you take appropriate precautions.

- Minimize the opportunity for vectors to contaminate cleaned and sanitized surfaces and harvest materials.

- Minimize the access or attraction of vectors to harvest buckets or totes kept in the garden, garage, or storage shed (for instance, do not leave damaged fruit in a harvesting bucket).

\section{Guiding Principles for Washing Fresh Produce Prior to Consumption or Short-term Storage}

The quality of any water that contacts fresh produce after harvest during cleaning and food preparation is widely recognized as the essential control point for human pathogens on fresh produce.

Washing, in combination with a disinfectant treatment, will reduce but not eliminate microbial contamination. Greater microbial reductions are achieved on smooth, waxy produce than on rough-textured or porous produce or on leafy greens. A number of produce spray cleaners and wash aids are being marketed now for home consumer use. We have tested several and have found that their range of effectiveness varies and is generally not significantly greater than that of water alone. Some products do have limited antimicrobial activity, but none is currently registered, as required by law, with the U.S. Environmental Protection Agency for home use as an antimicrobial wash.

Mechanical removal of soil and potential contaminants by brush-washing under running tap water is the recommended home practice. Antimicrobial agents are not generally recommended for home use, and washing produce with soap is not advisable.

Refrigeration is important for maintaining food quality and safety, but by itself it cannot be relied upon to provide sufficient protection from potential foodborne illness.

- Use only good-quality produce, free from open wounds or defects that may have allowed bacteria to become internalized. Avoid items that have visible sunken areas or areas of mold or decay.

- Cutting away decayed or damaged areas at least 1 inch beyond the edge of the defect is generally effective for produce that is to be consumed immediately or promptly refrigerated.

- It is far better to wash produce under running water than to batch-wash it in a basin. 
For optimal quality, many fruit and vegetables are ripened or stored at room temperature. The safety of uncut, good-quality produce is generally not impacted by room-temperature storage. Howeer, it is important that you al ways cover and refrigerate cut fruit and vegetables when preparing them in advance. Throw out cut fruit and vegetables if they have been held for longer than 2 hours at room temperature or longer than 1 hour at temperatures above $90^{\circ} \mathrm{F}\left(32^{\circ} \mathrm{C}\right)$.

For optimal quality, many fruit and vegetables are ripened or stored at room temperature. The safety of uncut, good-quality produce is generally not impacted by room-temperature storage. Howeer, it is important that you al ways cover and refrigerate cut fruit and vegetables when preparing them in advance. Throw out cut fruit and vegetables if they have been held for longer than 2 hours at room temperature or longer than 1 hour at temperatures above $90^{\circ} \mathrm{F}\left(32^{\circ} \mathrm{C}\right)$.

\section{GETTING STARTED: RESOURCES TO UNDERSTAND AND MINIMIZE MICROBIAL RISKS TO FRESH PRODUCE}

Food Safety Fact Sheets and the EPA Consumer Handbook for Composting:

http://vric.ucdavis.edu

http://ucgaps.ucdavis.edu

Food Safety Begins On-the-Farm Brochure (English and Spanish):

http://www.gaps.cornell.edu

FoodSafe Program:

http://foodsafe.ucdavis.edu

Partnership for Food Safety Education:

http://www.fightbac.org

Foodborne Pathogens: The Bad Bug Book:

http://www.cfsan.fda.gov/ mow/intro.html

\section{GLOSSARY}

Graywater: Wastewater from baths, showers, clothes washers, and bathroom sinks that is collected and used for irrigation (predominantly sub-surface watering).

Green manure: Typically, a plant cover crop that is grown and then chopped and incorporated into the soil or allowed to decompose for the purpose of soil improvement. "Green manure" does not mean raw animal manure.

Foliar: Of or pertaining to the shoots, leaves, and other above-ground parts of plants.

Pathogen: Any agent that can cause disease. Some human pathogens such as Salmonella have been shown to grow on nutrients available from plants, and especially from fruits.

Vector: Any living organism capable of carrying and transmitting a pathogen. 


\section{FOR MORE INFORMATION}

You'll find detailed information on many aspects of food safety and postharvest handling in these titles and in other publications, slide sets, CD-ROMs, and videos from UC ANR:

Don't Give Kids a Tummyache!, publication 21586

Ready of Not? Planning for and Emergency, publication AN RP014

Postharvest Technology of Horticultural Crops, publication 3311

To order these products, visit our online catalog at http://anrcatal og.ucdavis.edu. You can also place orders by mail, phone, or FAX, or request a printed catalog of publications, slide sets, CD-ROMs, and videos from

University of California

Agriculture and Natural Resources

Communication Services

6701 San Pablo Avenue, 2nd Floor

Oakland, California 94608-1239

Telephone: (800) 994-8849 or (510) 642-2431, FAX: (510) 643-5470

e-mail inquiries: danrcs@ucdavis.edu

An electronic version of this publication is available on the ANR Communication Services Web site at http://anrcatalog.ucdavis.edu.

\section{Publication 8101}

(c) 2003 by the Regents of the University of California, Division of Agriculture and Natural Resources. All rights reserved.

The University of $\mathrm{C}$ alifornia prohibits discrimination against or harassment of any person employed by or seeking employment with the University on the basis of race, color, national origin, religion, sex, physical or mental disability, medical condition (cancer-related or genetic characteristics), ancestry, marital status, age, sexual orientation, citizenship, or status as a covered veteran (special disabled veteran, Vietnam-era veteran or any other veteran who served on active duty during a war or in a campaign or expedition for which a campaign badge has been authorized).

University Policy is intended to be consistent with the provisions of applicable State and Federal laws.

Inquiries regarding the University's nondiscrimination policies may be directed to the Affirmative Action/Staff Personnel Services Director, University of California, Agriculture and $\mathrm{N}$ atural Resources, 300 Lakeside Drive, 6th Floor, Oakland, CA 94612-3550 (510) 987-0096. For information about obtaining this publication, call (800) 994-8849. For downloading information, call (530) 754-5112.

pr-7/03-WJC/VFG

ISBN 978-1-60107-275-7

Partial support for the production and distribution of this publication is contributed by the University of California Division of Agriculture and Natural Resources and the National Good Agricultural Practices Training Program (USDA CSREES Agreement \#99-41560-0821).

This publication has been anonymously peer reviewed for technical accuracy by University of California scientists and other qualified professionals. The review process was managed by the ANR Associate Editor for Food and Nutrition. 